\title{
PRÁTICAS DE ESCRITA EM CIÊNCIAS BIOLÓGICAS: LETRAMENTOS ACADÊMICOS (RE)CONTEXTUALIZADOS
}

\author{
WRITTEN PRACTICES IN BIOLOGICAL SCIENCE TEACHING \\ DEGREE PROGRAM: RECONTEXTUALIZED ACADEMIC LITERACIES
}

\author{
Adriana Fischer ${ }^{1}$ \\ Silvania Faccin Colaço ${ }^{2}$
}

\begin{abstract}
RESUMO: Este artigo tem como objetivo analisar interaçōes de estudantes em práticas escritas de letramentos acadêmicos, a fim de caracterizar como ocorrem (trans) formaçōes de identidades docentes. A abordagem metodológica é qualitativa, com análise da fala de dois sujeitos participantes do PIBID, de um Curso de Licenciatura em Ciências Biológicas. A análise é realizada pelas marcas discursivas na voz dos sujeitos - em diários, entrevistas e seminários avaliativos - como indicativas do papel dos estudantes diante de novas práticas de letramento. A base teórica ancora-se nos Novos Estudos do Letramento (STREET, 1995), com abordagem nos letramentos acadêmicos (LEA; STREET, 1998, 2006; LILLIS, 1999, 2001, 2003; FIAD, 2011; FISCHER, 2007, 2010, 2015), considerando-se questōes de valor, identidade e poder do grupo social. Além disso, abordam-se os estudos voltados à formaçấo de identidades (BAUMAN, 2005; HALL, 2011, 2012) e sobre a teoria bakhtiniana (BAKHTIN, 2011). As análises evidenciam os modos de interaçăo em práticas de letramento do Pibid, buscando-se estabelecer relaçôes com produçōes escritas realizadas pelos sujeitos. Os resultados mostram que a interaçâo na sala de aula da Educaçăo Básica possibilita a constituiçâo da identidade profissional na (trans)formaçăo do ser aluno para o ser professor.
\end{abstract}

Palavras-chave: Letramentos acadêmicos; Identidades na docência; Ciências Biológicas; Pibid.

ABSTRACT: This article aims to analyze the students' interactions in written academic literacies practices, in order to characterize how the transformations of teachers' identities occur. The methodological approach is qualitative, with the analyses of the speech of two PIBID participants, of a Biological Science Teaching Degree Program. The analysis is fulfilled by discourse markings in the subjects' voice - in diary, interviews and evaluative seminars - as the indicative of the students' role considering the new literacy practices. The theoretical basis finds contribution in the New Literacy Studies (STREET, 1995), with the approach in academic literacy (LEA; STREET, 1998, 2006; LILLIS, 1999, 2001, 2003; FIAD, 2011; FISCHER, 2007, 2010,

Universidade Regional de Blumenau (FURB), Programa de Pós-Graduaçâo em Educaçăo, Centro de Ciências da Educaçăo, Artes e Letras. Doutora em Linguística, UFSC. fischer.furb@gmail.com

Instituto Federal Farroupilha (IF-Farroupilha), Rio Grande do Sul. Doutora em Letras, UCPel-Pelotas. silvania.colaco@iffarroupilha.edu.br 
2015), considering value questions, identity and power of the social group. Besides that, the studies are focused in identities formation (BAUMAN, 2005; HALL, 2011, 2012) and in some aspects of bakhtinian theory (BAKHTIN, 2011). The analyses show the interactions ways in Pibid literacy practices, aiming to establish relations with written productions, accomplished by the subjects. The results demonstrate that the interaction in Elementary school's classroom, allows the professional identity changes on being students to be a teacher.

Keywords: Academic Literacy; Identities in teaching; Biological Sciences; Pibid.

\section{CONSIDERAÇÕES INICIAIS}

O presente artigo tem como objetivo analisar interaçóes de estudantes de um curso de Ciências Biológicas, participantes do Programa Institucional de Iniciaçăo à Docência (Pibid),com práticas escritas de letramentos acadêmicos, a fim de caracterizar como ocorrem (trans)formaçōes de identidades docentes. Interessam, nesse sentido, práticas acadêmicas e pedagógicas vivenciadas pelos estudantes, as quais săo contextualizadas (cf. GEE, 2001) em propostas singulares deste Programa e do curso de licenciatura em questâo. Em consequência, considera-se que os letramentos acadêmicos desses estudantes sâo gradativamente (re)contextualizados, em virtude dos esforços deles em se assumirem insiders (GEE, 2001) nas práticas com as quais interagem, mesmo em meio a tensóes e conflitos que os constituem como docentes em formaçâo.

Dessa forma, este artigo ancora-se na teoria dos Novos Estudos do Letramento (STREET, 1995, 2006, 2014; LEA; STREET, 1998; 2006;BARTON; HAMILTON, 2000), a fim de enfocar questóes relativas a práticas de letramentos acadêmicos e pedagógicos. Os letramentos, de acordo com os Novos Estudos do Letramento (STREET, 1995), constituem o conjunto de práticas sociais que envolvem leitura e escrita. Usa-se o termo letramentos acadêmicos em referência ao conjunto de práticas sociais que envolvem leitura e escrita nos contextos da universidade e com finalidade acadêmica, em que os estudantes participam de aulas, seminários, congressos, simpósios, cursos, com apresentaçăo oral de trabalho ou publicaçăo de artigo científico, para uma comunidade acadêmica relacionada à área, sendo que a interaçăo entre os participantes é de troca de conhecimentos científicos. Nessas práticas, ocorrem também os letramentos pedagógicos (COLAÇO, 2015), que văo além de contextos acadêmicos, pois fazem parte de práticas pedagógicas em escolas de Educaçăo Básica, em aulas e vivências do contexto escolar, onde a interaçăo é voltada à docência, com o objetivo de formar o professor. Embora sejam práticas integradas, convém essa distinçâo terminológica, a partir do contexto de interaçăo e, principalmente, da funçáo das práticas nos processos interativos dos sujeitos com os outros e com os conhecimentos.

Em qualquer contexto de interaçăo, convém considerar os interlocutores, o contexto situacional e as intençôes enunciativas. Nesse processo discursivo, enfoca-se o enunciado (BAKHTIN, 2011), pois existem convençôes sociais, hierarquias, maneiras de se manifestar que mudam de acordo com os contextos. Assim, torna-se relevante refletir sobre a linguagem no lugar e no tempo em que está sendo usada. Isso mostra que os sentidos năo săo fechados e que o enunciado é único e irrepetível. A posiçâo do interlocutor é que determina a relaçăo enunciativa, estabelecendo sentidos que podem ser depreendidos. Considera-se, assim, que a voz do sujeito é acompanhada de múltiplas vozes, que 
o discurso nunca é neutro e pode revelar muito de seu valor no enunciado da interaçáo com os outros. E é nesse processo dialógico que o sujeito se constitui.

Nessa perspectiva, apresenta-se uma análise qualitativa de depoimentos de dois sujeitos participantes do Pibid do Curso de Licenciatura em Ciências Biológicas, de um Instituto Federal (IF), localizado na regiâo central do Rio Grande do Sul. A análise é realizada pelas marcas discursivas na voz dos sujeitos - em diários reflexivos, entrevistas semiestruturadas, textos de memórias e seminários avaliativos - como indicativas das interaçôes dos estudantes, principalmente em práticas escritas de letramentos - foco deste artigo-durante a participaçâo em três anos e meio no Programa (março/2010 a agosto/2013). Os dados se sustentam nas "histórias do vivido" (NÓVOA, 1992), pois advêm dos relatos dos sujeitos.

A fim de contemplar o objetivo do artigo, este apresenta uma seçăo sobre correntes teóricas, incluindo os Novos Estudos do Letramento, questóes relativas à concepçăo dialógica da linguagem e aspectos sobre construçâo de identidades. A seçăo seguinte traz enfoques metodológicos, que explicam a conduçâo da pesquisa no curso de licenciatura indicado. Adiante, o artigo centra-se nas análises acerca das práticas escritas de letramentos, com discussôes sobre o relatório de prática e o artigo científico por dois acadêmicos do Pibid, as quais contribuem para abordagens em torno da(trans) formaçăo de identidades docentes. As análises procuram interpretar como săo as identidades no início do processo de participaçăo no Pibid, em relaçăo às expectativas e representaçóes dos acadêmicos, a fim de abordar como os estudantes vâo se (trans) formando e tomando consciência dessa (trans)formaçáo.

\section{AS PRÁTICAS DE LETRAMENTO PEDAGÓGICO: A INTERAÇÃO DIALÓGICA NA FORMAÇÃO DE IDENTIDADES DE PROFESSORES}

Os Novos Estudos do Letramento (STREET, 1995, 2006; LEA, STREET, 1998, 2006; BARTON; HAMILTON, 2000; GEE, 1999, 2001) enfatizam a necessidade de se considerar o ambiente social de interaçăo, em práticas de letramentos voltadas às necessidades de uso social, portanto, em práticas sociais, que oportunizam o uso da linguagem em situaçôes concretas ligadas à experiência de sujeitos no mundo material e social (GEE, 2001).Esse enfoque prevê a relaçâo dos sujeitos com a leitura e a escrita por meio de representaçôes, valores e ideologias da cultura dos grupos sociais, de acordo com práticas sociocomunicativas a que estejam expostos.

$\mathrm{Na}$ perspectiva sociocultural dos letramentos, ${ }^{3}$ Gee (2001) considera que os Discursos "integram maneiras de falar, ouvir, escrever, ler, agir, interagir, acreditar, sentir (usando vários objetos, símbolos, imagens, ferramentas e tecnologias) para constituir significativas identidades e atividades socialmente situadas" (2001, p. 719), caracterizando que é preciso ter consciência de que há Discursos ${ }^{4}$ diferentes.

\footnotetext{
3 O termo "letramentos" está sendo usado no plural, para contemplar as diversas práticas sociais em que os sujeitos estâo inseridos.

4 Optou-se por seguir o uso do termo segundo Gee: “Discursos” (com D maiúsculo e no plural) no sentido de o sujeito aprender novas linguagens sociais, diferenciando de "discurso", termo usado para se referir apenas à linguagem em uso.
} 
Nas interaçōes sociocomunicativas, quanto mais um sujeito assume papéis distintos, melhor desenvolve seus "kits de identidade" (GEE, 1999, 2001), que demonstram a existência de diferentes formas de ser no mundo, como produto social e histórico (GEE, 1999; FISCHER, 2007).

Por serem compreendidos socialmente, os letramentos também se referem a práticas educacionais e formais. Nessa direçăo, considerando que o contexto acadêmico se constitui por inúmeras práticas de letramentos, pesquisas voltadas aos letramentos acadêmicos (LEA; STREET, 1998, 2006; STREET, 2009, 2010; LILLIS, 2001, 2003, 2009; LILLIS; SCOTT, 2007; FISCHER, 2007, 2010, 2015;FIAD; SILVA, 2009) buscam analisar a relaçâo do aluno, na leitura e na escrita, com os sentidos que ele constrói, gradativamente, nessas práticas.

No contexto de produçăo acadêmica, existe um interlocutor exigente, de acordo com os Discursos dessa esfera de enunciaçăo, diferente das situaçôes informais de uso da linguagem. Esses Discursos constituem os letramentos dominantes (BARTON; HAMILTON, 2000) da esfera universitária, relacionados às práticas de organizaçôes formais, padronizados e definidos de acordo com os efeitos formais da instituiçăo ou com áreas de conhecimentos científicos. Ao tentarem construir seus Discursos (GEE, 1999), em diferentes práticas acadêmicas, os estudantes seguem os Discursos dominantes legitimados por professores em âmbito universitário, podendo aceitá-los, negá-los ou mesmo contestá-los.

As açōes de estudantes universitários sâo constantemente conectadas com práticas de leitura e escrita, e os modelos culturais ditam o que é aceitável de acordo com um modelo particular, a exemplo da produçâo de relatórios e de artigos científicos. Nesse sentido, relaçōes de poder determinam modelos culturais (GEE, 2001), os quais indicam o que conta como conhecimento em um dado contexto (LEA; STREET, 2006). Assim, para se compreender interaçôes de estudantes com práticas escritas de letramento, náo é possível separá-los do contexto e dos recursos envolvidos em suas aprendizagens.

Convém destacar a natureza desigual dos letramentos (STREET, 2006), devido a relaçōes de poder que estăo enraizadas em práticas sociais. Se alguns letramentos săo legitimados por instituiçóes, outros, em consequência, săo desvalorizados. Universidades, por exemplo, tendem a suportar práticas dominantes de letramento, pois se constituem como contextos institucionalizados de conhecimento, incorporados em relaçôes e domínios sociais (BARTON; HAMILTON, 2000). Essas práticas se configuram em seminários, resumos, resenhas, artigos científicos, aulas expositivas e dialogadas, entre outras. Os letramentos acadêmicos tendem, portanto, a legitimar Discursos sobre a leitura e a escrita associados à escolarizaçăo, determinando como se deve ler, escrever e falar nesse domínio e quem está autorizado a fazer isso. Para evitar a exclusâo de sujeitos inseridos em práticas de letramentos năo legitimadas, é preciso criar condiçóes para que aqueles que năo têm contato com letramentos dominantes possam ter possibilidades de atuar em contextos acadêmicos, interagindo por meio de seus modos de falar, agir, valorizar, interpretar e usar a linguagem (GEE, 2001).Nos cursos de formaçáo de professores, programas de inserçăo na atividade docente - como o Pibid - demonstram a possibilidade de inclusâo dos sujeitos em novas práticas de letramento legitimadas na docência. A interaçăo em sala de aula da Educaçăo Básica promove situaçôes de usos de diversos gêneros discursivos próprios da esfera escolar, 
bem como a incorporaçăo de Discursos dessa esfera, fazendo com que os sujeitos se sintam insiders (GEE, 2001) em práticas situadas de letramento.

No Pibid, os gêneros discursivos exigem letramentos próprios da esfera acadêmica e pedagógica, com uma linguagem especializada, que constitui "gêneros discursivos secundários" (BAKHTIN, 2011, p. 263), mais complexos, como resenhas, resumos, artigos, projetos e relatórios, em que predominam Discursos científicos e pedagógicos, em convívio cultural organizado. Esses gêneros se constituem com apoio de "gêneros discursivos primários" (BAKHTIN, 2011, p. 263), da comunicaçăo espontânea, e essa relaçăo, junto ao processo histórico de formaçăo dos gêneros secundários, vem esclarecer a natureza do enunciado, em que circulam correlaçōes entre língua, ideologias e visôes de mundo. Desse modo, a abordagem a partir dos gêneros discursivos torna-se um dispositivo usado neste artigo para analisar práticas sociais no Pibid, na sua pluralidade, conforme propôe o estudo sociocultural dos letramentos.

Concebe-se a linguagem como um processo de interaçăo dialógica, que se estabelece entre enunciados na comunicaçăo verbal, pois a voz do sujeito nunca está sozinha, o que o sujeito fala revela ele mesmo e os outros (BAKHTIN, 2011). Os Discursos têm sujeito e posiçăo; nunca săo neutros. O importante é compreender qual seu valor no enunciado. Cada enunciado é uma unidade básica, signo no contexto, único e irrepetível, pois se fala de maneira diferente, de acordo com as situaçóes comunicativas. 0 enunciado encontra-se inserido em esferas de atividades, que sâo "regiōes de recorte sócio-histórico-ideológico do mundo, lugar de relaçóes específicas entre sujeitos" (SOBRAL, 2009, p. 121). A esfera de atividade determina as relaçóes específicas dos sujeitos. Uma esfera cria espaços; dentro das esferas, existem as práticas; e, dentro delas, os enunciados. Assim, pode-se dizer que, nas esferas acadêmica e pedagógica, existem interaçóes próprias desses espaços, com práticas situadas em que circulam enunciados que participam das atividades dos sujeitos, de uma forma dialógica.

Abordam-se, assim, gêneros discursivos inseridos em práticas de letramentos predominantes no Pibid de Ciências Biológicas. Nessas práticas, os gêneros assumem funçōes, exigem conhecimento de valores, relaçôes de poder, contextos e usos de acordo com cada prática social, constituindo saberes pedagógicos nas práticas de letramento do Pibid. Pela análise das falas dos sujeitos, procura-se estabelecer relaçōes entre o que os sujeitos escrevem no Pibid e a sua (trans)formaçăo de alunos em professores, numa interaçấo dialógica da linguagem, em que os estudantes assumem uma nova ótica de açấo, de acordo com novas práticas sociais.

Salienta-se que as fronteiras entre ser aluno e ser professor sâo muito tênues na formaçăo inicial de professores, pois o aluno que está exercendo o papel de professor, em alguns momentos, pode se sentir em conflito entre esses dois papéis. Considera-se que os estudantes de um curso superior em licenciatura assumam as identidades acadêmico-pedagógicas, a fim de se inserirem no contexto universitário e de construírem diferentes letramentos. Vale lembrar que identidade nâo é apenas um produto acabado ou que surge de uma hora para outra, mas "um lugar de lutas e de conflitos, um espaço de construçăo de maneiras de ser e de estar na profissăo" (NÓVOA, 1992) constituindo um processo de formaçăo contínua.

Para Hall (2011), "as identidades săo construídas por meio da diferença", na "relaçăo com o Outro", com o seu "exterior constitutivo" (HALL, 2011, p. 110). Assim, ao se 
observar a construçăo das identidades de professor, pode-se afirmar que, quando se define como aluno, o sujeito tem consciência de que lhe faltam características para ser denominado professor, pois algo lhe falta; quando se diz professor, o sujeito identifica seu pertencimento a uma comunidade que possui características que a representam, diferenciando-o de outra profissâo. Silva (2012) considera identidade e diferença como o resultado de atos de criaçấo linguística que precisam ser compreendidos nos sistemas de significaçăo, nos quais adquirem sentido. Para o autor, identidade e diferença precisam ser produzidas, nomeadas, visto que náo sâo elementos da natureza, mas criaçóes sociais e culturais, pois "somos nós que as fabricamos, no contexto de relaçôes culturais e sociais" (SILVA, 2012, p. 76). Há também questôes culturais que envolvem a identidade, pois as pessoas estâo inseridas em contextos globais e locais de interaçấo, possibilitando algumas oposiçóes dentro desses contextos, seja de classe, de cor, de gênero, de profissăo, ou de outra ordem.

Identidade e diferença precisam ser representadas, pois somente a partir da representaçâo adquirem sentido (HALL, 2011).Esta é compreendida por Silva (2012) como uma forma de atribuir sentido, um sistema linguístico e cultural, o qual é ligado às relaçóes de poder. Para Woodward, "a representaçăo, compreendida como um processo cultural, estabelece identidades individuais e coletivas, e os sistemas simbólicos nos quais ela se baseia fornecem possíveis respostas às questóes: quem sou? quem eu poderia ser? quem eu quero ser?" (WOODWARD, 2012, p. 17). Mais do que isso, segundo Hall, o conceito de identidade supera essas questōes, pois é preciso ver em "quem nós podemos nos tornar", "como nós temos sido representados" e "como essa representaçăo afeta a forma como nós podemos representar a nós próprios" (HALL, 2011, p. 109). No caso deste artigo, é importante para os docentes dos cursos de formaçăo de professores, compreenderem como ocorre a (trans)formaçăo daquilo que o sujeito, acadêmico em formaçáo é, naquilo que ele quer ser, referente às representaçôes de aluno e de professor.

Para Hall, toda identidade tem necessidade daquilo que lhe "falta" - mas nunca há um ajuste completo, uma totalidade (HALL, 2011). A identidade é resultado da diferença ao encarar os outros, diante de posiçóes distintas, dentro dos jogos de poder das relaçōes sociais.Na constituiçâo das identidades profissionais, entram em questăo aspectos relacionados ao que falta para exercer uma determinada profissáo, concernente a Discursos, valores e saberes docentes, competências e comportamentos próprios da área de educaçăo e da área específica, como no caso da formaçăo de professores de Ciências Biológicas, foco deste artigo.

As identidades da docência referem-se năo só ao papel exercido na sala de aula, mas também ao relacionamento com colegas, como membro pertencente a um grupo e ainda a uma posiçăo social na comunidade, numa "discursividade de vozes que ecoam em torno do aluno" (BOHN, 2005, p. 97). O estudante da licenciatura passa a fazer parte de um novo contexto, novos eventos pedagógicos, em que deixa sua posiçấo discente para ocupar outras identidades na escola, próprias do docente. Ele participa de reuniôes com colegas professores, com dirigentes da instituiçấo, com pais dos alunos, relaciona-se no ambiente de circulaçăo de professores na escola, participa dos Discursos desses grupos e se posiciona conforme sua condiçăo de professor. Nessas relaçóes, o outro é aquele para quem ele sente que precisa "parecer" professor (BARTLETT, 2007), independente de "sentir-se" ou náo como tal. 


\section{ENFOQUES METODOLÓGICOS}

Para analisar interaçóes de dois estudantes em práticas escritas de letramentos pedagógicos, a fim de caracterizar como ocorrem (trans)formaçōes de identidades docentes, usa-se a análise descritiva de dados, amparada na pesquisa qualitativa (BOGDAN; BIKLEN, 1994, BAUER; GASKELL, 2002, DENZIN; LINCOLN, 2006).Em consonância com pressupostos da pesquisa qualitativa, procura-se conhecer a instância em particular das práticas de letramento pedagógico no domínio acadêmico de dois sujeitos, integrantes do Pibid do Curso de Licenciatura em Ciências Biológicas; bem como compreender essa instância em sua complexidade, pelas trajetórias específicas dos sujeitos participantes das interaçóes nas práticas de letramento em análise. Para tal, realizou-se uma pesquisa longitudinal, em que săo analisados os dados de um período de três anos e meio (março/2010 a agosto/2013) de dois sujeitos.

Nas representaçôes dialéticas que surgem na interaçăo dos sujeitos em práticas pedagógicas do Pibid, busca-se a memória reconstrutivadesses sujeitos (POLLAK, 1992) com apoio dos instrumentos investigativos. Compreende-se a importância de os acadêmicos falarem de si e de suas práticas, a fim de refletirem sobre identidades profissionais. Para Kleiman (2006), há "uma representaçâo dialética entre a representaçăo individual de si mesmo e a representaçăo que os outros têm do indivíduo" (KLEIMAN, 2006, p. 79). Nesse sentido, os letramentos críticos (GEE, 1999) auxiliam esses professores em formaçăo a sinalizarem(trans)formaçōes - quando há, efetivamente - pelas quais passam no período deformaçăo e açăo docente.Ressalta-se, aqui, conforme este autor, que os letramentos críticos representam modos de participaçâo em práticas sociais, compreendem sentidos construídos pelos sujeitos às práticas sociais, com apoio de Discursos secundários, do uso de metaconhecimento especializado, os quais dâo suporte à emancipaçâo social, capaz de conceder a eles poder de participarem de letramentos dominantes, de questionar, de analisar letramentos de maneira crítica.

Convém, assim, destacar que as análises aqui apresentadas se constituem num olhar de interpretaçāo sobre os relatos de dois professores em formaçāo, trazendo "fragmentos" de histórias vividas. Analisam-se os Discursos dos sujeitos, para se compreenderem essas histórias, pois, segundo Bakhtin (2011), cada ato enunciativo é único, irrepetível e, portanto, acredita-se que năo pode ser reproduzido tal como ocorreu de fato, mas como o falante se significa. Nesse sentido, de acordo com Bakhtin (2002), os sujeitos sāo responsáveis éticos por seus enunciados. A partir da materialidade linguística dos instrumentos de análise, têm-se as marcas discursivas que anunciam o lugar histórico e social do sujeito, sua posiçấo discursiva, como circula entre Discursos e faz circular Discursos.

\section{Pibid como espaço de formaçáo}

O contexto da pesquisa é o grupo do Pibid do Curso de Licenciatura em Ciências Biológicas de um Instituto Federal do Rio Grande do Sul. No Pibid, os estudantes, em duplas/grupos, realizam projetos de intervençăo em escola de Educaçăo Básica, sob a supervisăo de um responsável pelo Programa na escola, chamado de supervisor/a do Pibid e sob a orientaçấo de um profissional (professor/a universitário/a) do Programa 
na Instituiçáo Formadora. Os estudantes recebem um auxílio em forma de bolsa mensal, para cumprir uma carga-horária de 20 h semanais. ${ }^{5}$

No Programa, os estudantes realizam atividades que envolvem práticas de letramento, em diversos gêneros discursivos. No planejamento, osestudantes realizam um diagnóstico, a fim de conhecer a realidade da escola em que vấo atuar e, posteriormente, selecionam um tema a ser estruturado didaticamente e desenvolvido junto à turma, considerando os problemas da comunidade em que a escola está inserida. Considera-se que o projeto de atividades seja o ponto inicial para a realizaçâo da prática docente, pois é nele que os professores em formaçâo irâo refletir sobre o tema da implementaçáo na escola, estabelecer objetivos, para ter uma ideia clara das finalidades daquela prática, a fim de verificar os caminhos a percorrer e projetar as práticas pedagógicas. O projeto de atividades é visto, assim, como uma segurança para a açâo docente.

Após a realizaçâo dessa atividade, os estudantes planejam as aulas a serem desenvolvidas, em conjunto e de forma colaborativa. Elaboram seus planos de aula, em que acionam leituras realizadas, numa recontextualizaçăo de saberes para a sala de aula. É o momento em que os universitários, em processo inicial de docência, aprendem a adequar a aula ao tempo previsto, estabelecer objetivos claros e plausíveis, delimitar o enfoque do conteúdo, escolher encaminhamentos metodológicos para a realizaçâo das atividades, entre outras decisôes. Posteriormente, realizam a"implementaçăo", segundo linguagem em uso no Pibid, que se configura como o conjunto de aulas a serem encaminhadas na escola de Educaçăo Básica, semestralmente, em alguns períodos de aula, conforme negociaçōes com a escola.

Ao longo de todo o semestre, os estudantes apresentam relatórios escritos em diários reflexivos e também oralmente, em seminários, para reflexăo e avaliaçâo das práticas realizadas, a fim de traçar novas propostas.O relatório de prática tem a funçâo de registrar as atividades realizadas e representa mais um momento de reflexăo sobre a prática pedagógica. A elaboraçâo do relatório participa da (trans)formaçăo do ser estudante para o ser professor, no sentido de que a prática pedagógica foi realizada e as eventuais dificuldades enfrentadas, delas surgindo novas aprendizagens. $O$ registro das impressóes dos estudantes, pela sua própria voz, pode apresentar, de forma reflexiva, um panorama de toda a prática docente realizada.

A partir desses encaminhamentos, sâo produzidos artigos científicos a serem publicados e apresentados em eventos da área, com finalidade de compartilhar experiências e divulgar as atividades do grupo. A construçâo do artigo científico passa a ser um "desafio" discursivo, pois é um gênero específico do contexto acadêmico, com o qual os estudantes nâo tinham familiaridade e para o qual năo possuíam preparo. Convém destacar que a produçăo de artigos científicos năo é uma norma no Pibid, mas uma produçấo escrita de letramento como resultado da necessidade de diálogo com outras Instituiçóes, com outros docentes e pesquisadores, a fim de trocar experiências sobre as práticas realizadas e também como forma de exercer uma prática acadêmica que envolve o uso de Discursos especializados da área pedagógica.

Este dado se refere ao período de geraçăo de dados. Com mudanças no Pibid, a carga horária passou para 32h semanais. 
O Pibid, como espaço de práticas acadêmicas e pedagógicas, configura-se em um espaço colaborativo à formaçăo prática e pedagógica do professor, tendo fundamentaçăo teórica, orientaçăo metodológica nos encontros do grupo, contato permanente com ambientes da docência, momentos de análise das práticas realizadas, estudo de casos específicos vivenciados, entre outras açōes. Além disso, pelo acompanhamento e participaçăo nos seminários de avaliaçăo, os professores das escolas, inscritos no Pibid, têm papel relevante no processo de formaçấo profissional da universidade, visto que podem opinar, contribuir e se inteirar do currículo de formaçăo inicial de professores, podendo ainda rever as suas próprias práticas de ensino.

\section{Caracterizaçăo dos sujeitos}

Os depoimentos que compôem o corpus de análise, em enfoque neste artigo,advêmde dois sujeitos - Vítor e Letícia ${ }^{6}$ - escolhidos pelas suas trajetórias singulares. Embora os sujeitos selecionados sejam caracterizados ao longo da análise de dados, pelas suas trajetórias, faz-se, a seguir, com base em seus próprios relatos, uma descriçâo prévia a título de apresentaçâo inicial, a fim de que se possa olhar para os sujeitos de forma situada.

O nome Vítor é de origem latina - Victor - e foi escolhido por significar "vitorioso", correspondendo ao perfil do sujeito, que teve muitos desafios na vida, e, no momento de geraçăo dos dados, pelo seu idealismo, força de vontade e empenho, sua história dá indícios de que é um vencedor. O sujeito teve formaçăo de Ensino Médio Técnico em Agropecuária e ficou vinte e dois anos afastado da escola, dedicando-se ao trabalho na lavoura, por tradiçấo familiar. Nesse período de afastamento dos meios escolares, constituiu sua família e trabalhou naquilo que gostava. Vítor representa o perfil dos estudantes que concluíram a Educaçăo Básica e ficaram algum tempo sem estudar, buscando o curso de Licenciatura em Ciências Biológicas sem ter muita certeza se era isso mesmo que queriam, alguns até por falta de opçōes. Vítor destaca-se por seu dinamismo e envolvimento nas atividades acadêmicas do Curso, pelo entusiasmo ao falar de sua trajetória de formaçâo, pelo interesse nas questôes educacionais e pela sua facilidade de comunicaçâo.

O nome Letícia tem origem no latim - Laetitia -e significa "alegria, prazer, felicidade". Esse nome corresponde às características da estudante, que demonstra sua realizaçấo com o curso e com a escolha da profissăo, convicta de sua vontade de ser professora, que já existia desde criança. Desde muito cedo, brincava de ser professora, ideal que a acompanhou ao longo de toda sua escolarizaçăo. Letícia representa o perfil da maioria dos estudantes participantes do grupo do Pibid, que concluíram a Educaçáo Básica e logo ingressaram no curso superior, buscando o curso de Licenciatura em Ciências Biológicas, por se sentirem interessados pela docência e/ou pela área de Biologia desde muito cedo. Letícia destaca-se pela responsabilidade, dedicaçăo e satisfaçăo nas tarefas acadêmicas, além da força e empenho em vencer sua timidez ao longo das vivências acadêmicas e pedagógicas.

$6 \quad$ Nomes fictícios, para preservar a identidade dos sujeitos. 


\section{Instrumentos de geraçáo de dados}

Para atender à concepçâo teórica deste estudo, que destina atençâo para o contexto das práticas sociais, numa perspectiva etnográfica, optou-se por uma análise longitudinal, para acompanhar a trajetória dos sujeitos na sua inserçăo no Pibid (março/2010 a julho/2013). Foram analisados os relatos/depoimentos orais e escritos produzidos pelos sujeitos durante esse período de participaçâo no Programa, a partir de suas práticas de letramento.

Os instrumentos de geraçáo de dados utilizados e que servem de apoio para discussăo dos resultados neste trabalho săo:(a) diário reflexivo de registro das atividades e impressóes sobre a participaçăo no Pibid; (b) entrevistas realizadas em abril/2012, janeiro/2013 e agosto/2013; (c) seminário avaliativo, realizado com todo o grupo do Pibid, no final de cada semestre.Os trechos de depoimentos selecionados para este artigo săo passagens que chamaram atençáo por demonstrarem, pelas marcas discursivas, indícios das (trans)formaçōes de aluno em professor no Pibid.

O diário reflexivo é um gênero discursivo constituído no âmbito das práticas do Pibid, como instrumento para registrar as atividades realizadas, evidenciando os Discursos dos professores em formaçấo na sua trajetória formativa. É uma exigência do professor orientador do projeto, a fim de acompanhar as atividades realizadas pelos bolsistas ao longo da experiência. Considera-se um reflexo das práticas, porque tem a funçăo de passar a imagem do que foi realizado em todos os momentos de participaçăo no Programa, com um olhar crítico do próprio estudante sobre suas práticas de letramento no Pibid.Assim, o diário reflexivo é incorporado dentro do amplo conjunto de práticas sociais pedagógicas associadas com as atividades de planejar aulas, realizar projetos, dar aulas, participar de reuniōes e seminários da área, entre outras, em que o professor em formaçăo é sujeito da linguagem, trazendo sempre a sua história.

A fim de poder confrontar os dados dos diários com outros instrumentos, foram realizadas três entrevistas individuais durante o período em que se realizou a coleta de dados (janeiro/2012 a agosto/2013): (a) a Entrevista 1foi realizada em abril/2012, após dois semestres de participaçăo dos sujeitos em práticas de letramento do Pibid, com foco nas dificuldades, conflitos e (trans)formaçôes de aluno em professor, para analisar como os estudantes se sentem na inserçăo em práticas pedagógicas; (b) a Entrevista 2 foi realizada em janeiro/2013, um ano após a primeira, com foco nos alunos da Educaçâo Básica como sujeitos discursivos e nos textos que circularam nas práticas, para compreender o processo de interaçăo em práticas pedagógicas; (c) a Entrevista 3 foi realizada em agosto/2013, focou leitura/produçăo textual do Pibid e as situaçōes comunicativas em que os gêneros discursivos circulam, para analisar a constituiçăo das identidades de professor nos modos de interaçăo do Programa.

Ao final de cada semestre, após a realizaçâo de diversas práticas de letramento no Pibid, săo realizados Seminários Avaliativos, para relato e reflexăo sobre as práticas pedagógicas ocorridas nas escolas. Participam desse evento o coordenador do Projeto, os supervisores das escolas e todos os estudantes bolsistas do Pibid. Cada grupo relata como foi sua prática, desde o planejamento até as aulas efetivadas, destacando as atividades realizadas, o envolvimento dos alunos nessas atividades, as dificuldades surgidas e como foram vencidas, os sucessos e insucessos das práticas 
e como se sentiram diante da situaçăo docente. Todos os participantes podem se posicionar, fazendo questionamentos ou mesmo dando sugestōes para novas práticas.

\section{Procedimentos de análise}

A fim de analisar interaçôes dos estudantes em práticas escritas de letramento no Pibid, recorre-se aos "movimentos dialógicos" (FISCHER, 2007, p. 105-106), que indicam os modos de interaçăo em práticas de letramento, com o(s) outro(s) e com o conhecimento, sendo que muitos sentidos deles emergem. Destacam-se dois desses movimentos para este artigo, conforme resumido a seguir: os movimentos confirmativos e os avaliativos, por serem regularidades de ocorrência presentes nos dados. Os confirmativos vêm reforçar Discursos e também acrescentar informaçôes a ideias às quais o sujeito se afilia; os avaliativos săo manifestados, especialmente, no sentido de revelaçăo de conflitos de identidade do sujeito. Assim, esses dois movimentos balizam as análises de dados nesteartigo, a fim de analisar interaçōes de estudantes em práticas escritas de letramentos acadêmicos.

Nas representaçōes dialéticas que surgem nos modos de interaçăo, busca-se a memória reconstrutiva dos sujeitos (POLLAK, 1992) em todos os instrumentos investigativos. Compreende-se a importância de os acadêmicos falarem de si e de suas práticas, a fim de refletirem sobre as identidades profissionais. Para Kleiman (2006), há "uma representaçâo dialética entre a representaçăo individual de si mesmo e a representaçăo que os outros têm do indivíduo" (KLEIMAN, 2006, p. 79). Nesse sentido, os letramentos críticos auxiliam esses professores em formaçăo a sinalizarem (trans) formaçóes - quando há, efetivamente - pelas quais passam no período de formaçăo e açăo docente.

\section{INTERAÇÕES EM PRÁTICAS DO PIBID: A ESCRITA ACADÊMICA (RE)CONTEXTUALIZADA}

Para cada prática escrita do Pibid, surgem novas formas de interaçâo, vindo a constituir, no conjunto, novos letramentos do sujeito. Os textos sâo produzidos em práticas situadas de acordo com os movimentos do Pibid, e, nessas práticas, surgem novos contextos, como eventos científicos e sala de aula na Educaçâo Básica, em que os sujeitos interagem e produzem leitura e escrita para essa interaçăo. Dessa forma, săo muitos os Discursos das esferas acadêmica e pedagógica que constituem os letramentos do professor em formaçăo. Em seus depoimentos sobre a escrita no Pibid, os estudantes citam vários gêneros discursivos produzidos com propósito tanto acadêmico como pedagógico. Entre esses gêneros, selecionaram-se dois para análise neste artigo, por serem gêneros de relato de práticas no Pibid e de divulgaçăo de resultados: o relatório e o artigo científico. A produçăo desses gêneros exige conhecimento dos contextos e finalidades para os quais sâo produzidos, o que é valorizado nesses contextos, a situaçâo comunicativa, a funçâo de uso, bem como as relaçôes com os interlocutores.

Os sujeitos integrantes do Pibid interagem em diversos contextos de práticas voltadas para a formaçâo profissional, sendo que, na interaçâo com os demais 
participantes dessas práticas, subjazem relaçōes de poder, de acordo com cada prática situada. Eles participam de interaçōes nas escolas, na universidade e em eventos científicos, como simpósios, seminários e encontros em outras instituiçôes de ensino superior. Nas escolas, existem as relaçóes de poder do currículo escolar, dos professores mais experientes, que trazem conhecimentos práticos e teóricos mais consolidados e, por consequência, Discursos já cristalizados; na universidade, as relaçôes de poder estăo presentes nos currículos dos cursos superiores, nos conhecimentos difundidos pelas diferentes disciplinas, nos Discursos especializados dos professores e nas leituras realizadas; nos eventos científicos, as relaçóes de poder indicam o que deve ser produzido e quem pode produzir os Discursos científicos, entre o público participante desses eventos, composto por estudiosos da área, pesquisadores, com diferentes graus de especialidade.

Nessa perspectiva, interpretar os textos produzidos pelos pibidianos, na relaçăo com os contextos onde circulam, auxilia, em consequência, na compreensâo da "história do texto" (LILLIS, 2009), que envolve práticas nas quais esses textos se inserem e respectivos sentidos construídos pelos sujeitos. Nesse contexto de produçăo, há um repertório de textos no diário reflexivo, que representa uma forma de o leitor imediato - o professor formador, que é o coordenador do projeto - acompanhar as transformaçôes construídas pelo estudante, na condiçâo de professor em formaçăo em práticas do Pibid. Com base nesses enfoques, nas subseçōes adiante, analisam-se os gêneros relatório e artigo científico, produzidos para discorrer sobre as trajetórias no projeto do Pibid.

\section{Uma forma de registro e reflexăo: o relatório de prática}

Após a realizaçăo da prática pedagógica, os estudantes săo orientados, como proposta do Pibid, elaborar o relatório de prática, no interior dos diários reflexivos, que têm a funçáo de registrar atividades realizadas. Esta produçáo representa um momento a mais de reflexâo sobre a prática pedagógica. A elaboraçăo do relatório participa da (trans)formaçăo do ser estudante para o ser professor, no sentido de que a prática pedagógica possibilita e exige novas aprendizagens e novos conhecimentos. O relatório é produzido na fase final de cada implementaçăo- conjunto de aulas realizadas no projeto semestral de prática pedagógica na Educaçăo Básica -em que o sujeito demonstra como vem construindo sua inserçáo nas práticas, a partir de uma reflexáo crítica.

Convém explicitar que o relatório de prática pedagógica é construído de duas formas, sendo um relatório individual escrito no diário reflexivo e outro produzido pelo grupo, por escola, com o auxílio da supervisora, que também participa do seminário avaliativo.

Nesse processo de interaçăo com a produçấo escrita, os interlocutores săo o estudante e seu coordenador. Este acompanha o estudante, agora professor em formaçăo, em suas práticas de letramento acadêmico e pedagógico, com apoio de diferentes gêneros discursivos. No relatório de prática, sâo evidenciadas as relaçôes de poder entre quem escreve e quem lê/avalia, isto é, o professor em formaçâo, na condiçâo de aprendiz, com os saberes de suas vivências, e o coordenador do Pibid, na posiçăo de quem organiza saberes e Discursos mais especializados de sua caminhada pedagógica e tem a funçăo de avaliar e orientar o processo. 
(1) Após as observaçóes da coordenadora, começamos a arrumar os relatórios, seguindo as sugestōes recebidas. (Letícia - Diário Reflexivo - jul/2010 Encontro de Estudos)

(2) A coordenadora sugeriu algumas modificaçôes no relatório para sua reescrita: mais clareza sobre os assuntos abordados; fazer citaçôes do material utilizado; revisar as teorias utilizadas. (Vítor - Diário Reflexivo - dez/2010 - Encontro de Estudos)

Em dois momentos diferentes, os professores em formaçâo se reportam às sugestóes da coordenadora do Pibid, sobre a escrita dos relatórios. Houve aceitaçăo das sugestōes, conforme o movimento confirmativo nas palavras de Letícia: "começamos a arrumar os relatórios, seguindo as sugestōes recebidas" (1). Vítor menciona os pontos destacados pela coordenadora para aprimoramento, sem contestaçâo alguma, demonstrando, também, aceitaçâo em relaçáo à interaçăo discursiva com a professora, evidenciando o movimento confirmativo.

Apesar das questôes de poder, que poderiam suscitar medos e inseguranças, os estudantes produziam relatórios com facilidade, segundo seus relatos:

(3) Fazer os relatórios foi tranquilo. Sempre relatava tudo que acontecia... Claro que, no início, nâo teve aquela fundamentaçâo teórica necessária. (Letícia Entrevista 1 - abril/2012)

(4) Construir os relatórios foi mais fácil do que os planejamentos. (Vítor Entrevista 1 - abril /2012)

O uso da expressăo temporal "no início" (3), relativamente ao aprofundamento teórico, indica a aquisiçăo de outros saberes, na construçăo de novos letramentos, trazendo indícios de que, no momento em que Letícia escreve esta parte do relatório, já năo é mais da mesma maneira, marcando que houve (trans)formaçăo discursiva. Vítor, por sua vez, considerou a escrita do relatório "mais fácil" em relaçáo aos planos de aula, num movimento avaliativo, com avaliaçăo positiva de sua prática de letramento. Pelos enunciados, há marcas de que os estudantes nâo tiveram dificuldades na escrita dos relatórios, provavelmente devido ao fato de que o relato da prática lhes era familiar, em virtude da proximidade com experiências realizadas em práticas anteriores de letramento escolar e mesmo no contexto acadêmico do curso em questăo. Além disso, deve-se considerar a maior familiaridade com os Discursos pedagógicos, pois, ao elaborar o relatório, já passaram por muitas leituras de fundamentaçăo teórica, já se inseriram em práticas sociais na Educaçâo Básica, além de já terem produzido outros gêneros, com fins pedagógicos, como o projeto de atividades e o plano de aula.

O relatório é uma norma do Pibid, mas também oferece a possibilidade de reflexâo sobre a prática realizada, a fim de que cada nova implementaçăo na escola ocorra com maior sucesso. Essa reflexăo é sugerida pela orientadora do Pibid na universidade, pois constitui também uma forma de acompanhamento das (trans)formaçóes do pibidiano. Além da autoavaliaçâo, os estudantes podem, mais uma vez, contar com a apreciaçâo e as sugestóes dos demais participantes do projeto, no momento da apresentaçăo em slides no seminário realizado após a conclusâo da prática na escola:

(5) Procuramos adaptar os planejamentos de acordo com as observaçóes feitas pelos professores e colegas participantes do Seminário de relato das implementaçōes. (Letícia - Diário Reflexivo - abr/2012) 
No seminário, conforme posto por Letícia, é avaliado o relatório da prática anterior. A partir das observaçóes do grupo, ela se preocupou com a (res)significaçâo dos planejamentos posteriores às sugestôes recebidas. No excerto (5), os termos "adaptar" e "de acordo com as observaçóes feitas" indicam um movimento confirmativo em relaçâo às vozes dos colegas e dos professores, com aceitaçăo das opiniōes sobre o relatório, sinalizando que as críticas poderăo servir para as novas práticas.

Nos seminários avaliativos, os alunos apresentam o relatório de tudo que foi realizado e suas impressóes sobre as práticas pedagógicas, com slides contendo o resumo das açóes e fotos que registram as atividades realizadas na escola. Os professores em formaçáo relatam seus conflitos, seus imprevistos, seus acertos e erros, mas principalmente, como se sentiram na inserçăo em práticas pedagógicas, revelando suas (trans)formaçóes acadêmicas e docentes ao longo da experiência. Assim, produzir o relatório torna-se um importante passo para o professor em formaçâo e, quando os desafios dessa prática de escrita săo enfrentados, Letícia afirma sua participaçăo como membro efetivo em mais um contexto - o contexto escolar das práticas pedagógicas.

(6) Com a apresentaçáo deste Seminário de Prática, pode-se ver a crescente evoluçấo e empenho, tanto dos bolsistas novos como dos mais antigos (Letícia Diário Reflexivo - set/2010 - Encontro de Estudos).

Num movimento avaliativo, a expressăo usada pela estudante "bolsistas novos" e "mais antigos" indica o lugar de onde ela fala, no mês de setembro de 2010, pois já se considera entre "os mais antigos", tendo em vista que começou sua participaçấo no início daquele ano, e outros colegas entraram no decorrer do mesmo ano. Essa interaçáo com os "novos" já lhe dá a condiçấo de se sentir capaz de ajudar a quem está começando, na voz de autoria e na situaçăo de poder em que ela se encontra.

A aprendizagem do gênero ocorre inserida em uma prática situada (THE NEW LONDON GROUP, 1996), pois o relatório é solicitado aos estudantes, como resultado das açôes relativas ao Pibid, servindo, assim, para o acompanhamento do trabalho, configurando-se como um dizer sobre o que foi feito, a fim de marcar reflexâo em torno do fazer docente. Por isso, a professora coordenadora olha os relatórios e dá orientaçóes para sua construçấo, comentando pontos positivos e também o que falta para ficar mais específico, dando sugestóes de melhoria na escrita.

(7) A coordenadora conversou com o grupo sobre diários, relatórios, artigos, apresentaçóes realizadas, salientando pontos que precisam ser melhorados. Também explanou sobre algumas confusóes feitas por nós durante a escrita do relatório. Atividades que nos fazem ver nossos erros nos ajudam a crescer cada vez mais, pois muitas vezes nos dizem que devemos melhorar, mas nâo apontam nossos erros. Dessa forma, nosso conhecimento é maior. (Letícia Diário Reflexivo, dez/2012 - Encontro de Estudos).

(8) A coordenadora observou individualmente cada trabalho e fez as observaçóes necessárias, ajudando a complementaçáo do mesmo. Sugeriu que todos acrescentassem as referências bibliográficas dos textos lidos. (Vítor - Diário Reflexivo - jun/2010 - Encontro de Estudos)

Esse contato com a coordenadora durante a construçăo dos textos indica novamente a instruçáo explícita (THE NEW LONDON GROUP, 1996), em que o professor guia o 
estudante com o uso de uma metalinguagem da prática de letramento, incluindo apoio e estímulo constantes aos estudantes, com esforços colaborativos. Ao salientar "os pontos que precisam ser melhorados" (7), a professora realiza a instruçăo necessária no acompanhamento do trabalho.

Na universidade, o professor formador espera que o aluno tenha respostas positivas em relaçăo às práticas pedagógicas com suporte nas teorias propostas no currículo do curso. Nessas relaçōes, pode acontecer a "prática do mistério"(FIAD, 2011, p. 361), caracterizada como a distância entre o que o estudante apresenta de letramentos e o que a universidade espera que ele apresente. Às vezes, pode ficar oculto o que o professor realmente espera da produçáo do aluno, por ser um pré-requisito esperado, por exemplo, a escrita do relatório de prática pedagógica, bem como quais os Discursos que circulam nas práticas pedagógicas. Por sua vez, o estudante também năo compreende, sempre, o que o professor está solicitando, por năo estar inserido nos letramentos das práticas pedagógicas. Destaca-se que a prática do mistério năo é "para sempre", pois, à medida que o estudante vai se inserindo em novas práticas de letramento, ele consegue estabelecer a equivalência entre os letramentos pedagógicos dos professores iniciantes e o que é esperado deles, que é a construçâo de letramentos, com segurança e autonomia ao planejar e executar suas práticas pedagógicas, correspondendo, assim, às expectativas dos professores e da Instituiçấo. Entretanto, mesmo com a instruçâo explícita, as dimensôes escondidas ou ocultas sâo constitutivas das práticas de letramento, pois nâo é possível explicitar todas as ideologias, sentidos, relaçóes de poder aos estudantes.

As práticas escritas de letramento sâo permanentes no Pibid, fazendo com que os acadêmicos tomem consciência dos modos de produçấo, em contextos acadêmico e pedagógico, e procurem ampliar saberes e práticas, conforme se confirma nos depoimentos "nos fazem ver nossos erros, nos ajudam a crescer cada vez mais" (7), "dessa forma, nosso conhecimento é maior" (7), em um movimento de comparaçâo com outras práticas de orientaçăo em que "dizem que devemos melhorar, mas náo apontam nossos erros" (7).Essa indicaçấo, de que outros profissionais "nâo apontam os erros", marca o que é esperado por eles, pela instituiçăo e nem sempre se torna explícito aos estudantes, pois se tratam de questóes ideológicas, de relaçóes de poder e autoridade, que vâo fazendo sentido gradativamente, à medida que esses estudantes vâo se inserindo, de modos muito particulares, em distintas práticas de letramento que envolvem conhecimentos acadêmico-científicos e pedagógicos. Evidencia-se, assim, na voz de Letícia (7) e Vítor (8), uma negaçaào à "prática do mistério" no Pibid, e uma valorizaçáo ao suporte dado pelos professores durante a escrita e reescrita de gêneros. Há observaçôes pontuais de apoio à atividade de escrita, conforme se observa na atitude da professora "Sugeriu que todos acrescentassem as referências bibliográficas dos textos lidos" (8). A escolha vocabular usada por Vítor "sugeriu" indica uma posiçâo mais dialógica que a professora assume diante do grupo: de quem orienta e dá sugestôes, sem imposiçóes, caracterizando um contexto colaborativo. Por tudo isso, pode-se dizer que ambos os estudantes demonstraram movimentos confirmativos na interaçăo com a coordenadora e a escrita dos relatórios de prática.

Posteriormente a essas discussōes internas do grupo, os estudantes do Pibid produzem artigos científicos para divulgar os resultados de suas experiências, relatando os processos envolvidos em práticas pedagógicas realizadas e expondo as reflexóes 
feitas pelo grupo. Vale ressaltar que a produçâo do artigo năo é uma prática obrigatória no grupo analisado, mas decorrente de um movimento inerente ao processo que ocorre no Programa, pois os pibidianos produzem artigos para viabilizar discussôes fora da Instituiçăo Formadora, chegando a outros contextos universitários, para uma reflexâo mais abrangente.

\section{Um desafio discursivo: 0 artigo científico}

Com apoio dos registros feitos nos relatórios, sâo construídos artigos científicos para publicaçấo em eventos na área de Educaçăo ou de Biologia. Letícia considera a construçâo do artigo científico como um "desafio", pois é um gênero específico do contexto acadêmico, com o qual nâo tinha familiaridade até ingressar no Pibid e para o qual năo possuía preparo:

(9) Cada artigo é um desafio, mas a cada etapa vamos superando as dificuldades e trilhando nossos caminhos. (Letícia - Diário Reflexivo - jun/2011 - Encontro de Estudos)

De acordo com os dados gerados na pesquisa, esses alunos do Pibid em Ciências Biológicas participam de eventos científicos - encontros, seminários, mostras, simpósios, congressos - como apresentadores de trabalho. Para tal, produzem, em grupos, os resumos e artigos científicos sobre as práticas pedagógicas realizadas, a serem apresentados na modalidade de comunicaçăo oral ou pôster, conforme os enunciados:

(10) Levamos trabalho em pôster e artigos para apresentar no evento... (Letícia Entrevista 1 - abr/2012)

(11) ...os artigos científicos, resumos, eram produzidos a partir de uma implementaçăo(sejam elas aulas, oficinas, ou demais experiências vivenciadas nas escolas)...para apresentar em algum evento (Letícia- Entrevista 3 ago/2013)

Nos excertos acima, Letícia menciona alguns gêneros discursivos - "pôster", "artigos", "resumos" - inseridos em novas práticas de letramento do Pibid - os "eventos" - das quais ela e seus colegas passam a fazer parte como sujeitos ativos e com autoria bem marcada. Essa produçáo provoca desafios entre os estudantes, pois săo práticas situadas, com Discursos especializados e com os quais eles nâo estavam acostumados.

No contexto de produçăo acadêmica, existe um interlocutor exigente, de acordo com os Discursos dessa esfera de enunciaçăo, manifestados por marcas discursivas, diferentes das situaçóes informais. E, no início das práticas do Pibid, há pouca familiaridade dos estudantes com a estrutura e os Discursos dos gêneros que circulam no domínio científico. Assim, na escrita do artigo científico, surgemconflitos no processo de socializaçấo acadêmica, pois este provoca insegurança diante dos usos da linguagem em novas práticas discursivas.

Muitos estudantes carregam um preconceito enraizado no senso comum, de que năo sabem escrever. Nessa perspectiva, ao ser questionado sobre os textos produzidos nas práticas do Pibid, Vítor expressa o conflito que fala e escrita representam para ele, um agricultor que volta a estudar depois de algum tempo afastado da escolarizaçáo: 
(12) ...tivemos bastante dificuldade na hora de escrever o artigo, porque como a gente quer colocar a linguagem falada... entâo esse que é o problema, na hora do artigo científico é totalmente diferente, a gente escreve horrores, mas é numa linguagem falada, depois começa a enxugar... (Vítor - Entrevista 1 - abr/2012)

Esse depoimento sinaliza que, apesar da inter-relaçăo entre práticas faladas e escritas na esfera acadêmica, normas/regras de uso da linguagem escrita impóem monitoramento constante, por parte do estudante, a fim de atender às expectativas institucionais da produçấo científica. Vítor deixa transparecer a preocupaçăo com o estilo (BAKHTIN, 2011) de seu enunciado escrito, pois precisa considerar, na linguagem científica, um auditório especializado, visto que o artigo científico dirige-se a um círculo específico de leitores, com um "determinado fundo aperceptível de compreensâo responsiva" (BAKHTIN, 2011, p. 302). O impacto da cultura daqueles que compóem esse círculo específico sobre o produtor do artigo tende a ser mais significativo do que o impacto de habilidades técnicas de escrita (STREET, 2014), pois estăo presentes significados culturais, relaçóes de poder e de autoridade sobre o que é o conhecimento científico e quem pode produzi-lo.

Vítor demonstra que consegue vencer as barreiras com a linguagem na prática de escrita do artigo, ao longo de sua inserçáo no Pibid, pela reescrita, com apoio da coordenadora e devido ao trabalho colaborativo com os colegas, constituindo, assim, letramentos acadêmicos numa nova comunidade de prática. ${ }^{7}$ É preciso considerar que a apropriaçăo de letramentos acadêmicos náo ocorre de uma só vez, mas faz parte de um processo que vai acontecendo com apoio de outros agentes de letramento nas práticas acadêmicas do Pibid. Percebe-se isso no relato a seguir:

(13) A coordenadora sempre junto...a gente mandou umas seis vezes o artigo até que deu por encerrado...O pior foi adequar a linguagem na escrita. [...] A maior dificuldade é essa, mas o grupo ajudou... a gente trabalha sempre junto... 0 dificultoso mesmo é colocar um artigo em revista... Mas hoje a gente já escreve bastante... talvez năo esteja adequado ao nível que deve estar, mas a gente vai crescendo, é uma construçâo...(Vítor - Entrevista 1 - abr/2012)

O estudante, num movimento avaliativo, reforça que a "maior dificuldade" foi com a linguagem científica, também "colocar um artigo na revista". Apresenta, em acréscimo, açôes que ocorrem no Pibid, tais como:"a gente mandou umas seis vezes o artigo até que deu por encerrado", referindo-se ao processo de reescrita, em que a coordenadora atuou como agente de letramento comesses pibidianos, inserindo-os, gradativamente, em práticas e eventos científicos. O sujeito dá mostras, também, de que desenvolveu a consciência do processo pelo qual vem passando, isto é, com a participaçăo nessas práticas e o uso de textos que nelas transitam, ele vai melhorando sua escrita. Na apresentaçâo de trabalhos em eventos, na publicaçâo dos textos em periódicos da área, no contato com outras instituiçōes científicas, o estudante amplia conhecimentos sobre as relaçōes de poder existentes nos veículos de publicaçăo, como periódicos científicos, e nos Discursos especializados de um público exigente. Esses Discursos fazem parte de

Comunidade de prática entendida como a relaçâo entre o domínio, a comunidade e a prática (WENGER, 1998). Transpondo para este estudo, podem-se associar esses componentes da seguinte forma: o domínio corresponde a uma área do conhecimento (Ciências Biológicas); a comunidade é o elemento central, em que ocorrem as interaçōes entre as pessoas (o grupo do Pibid); e a prática é o conhecimento e a experiência compartilhada pelos membros (práticas acadêmicas/pedagógicas). 
normas institucionais que devem ser compreendidas pelos pibidianos, neste caso, para que se insiram como insiders - membros efetivos - nesta comunidade acadêmica, que inclui o processo complexo de publicaçáo científica.

Vítor assume gradativamente a identidade acadêmico-científica, a fim de se inserir no contexto universitário. Ao tentar se inserir nas práticas do Pibid, ele segue ou faz uso de Discursos dominantes legitimados pela comunidade universitária. Mas, para se tornar fluente, precisa entender o funcionamento dos diferentes gêneros discursivos que fazem parte dessas práticas. O estudante passa a conhecer e usar as regras sociais que integram as práticas de letramento e que regulam o uso e a distribuiçấo de gêneros discursivos.

Por conseguinte, esse modo gradativo de inserçâo nessas práticas evidencia a trajetória do estudante, a qual reforça a possibilidade de reposicionar os Discursos do "déficit do letramento" (GEE, 1999) no Ensino Superior, que transparecem em dizeres sobre o náo conhecimento de gêneros discursivos na universidade por parte dos estudantes.

Com base nos dados enfocados neste artigo, destaca-se o quanto é importante que diferentes áreas do conhecimento proporcionem aos alunos o contato com o uso de textos desse domínio mais científico e especializado, pois, como se acompanha na fala de Vítor, é na inserçăo em práticas sociais que fazem usos desses gêneros e que se vâo construindo os letramentos acadêmicos.

Segundo Fiad (2011), os professores precisam se preocupar em partir dos letramentos que os estudantes trazem para a universidade e, aos poucos, introduzi-los em práticas mais complexas e específicas de letramento no contexto acadêmico. Veja-se o depoimento de Vítor em relaçăo a seus letramentos prévios:

(14) Eu voltei à estaca zero praticamente, depois de 23 anos fora da escola, eu voltei... e na minha época náo existia isso... e era técnico... totalmente profissionalizante..." (Vítor - Entrevista 1 - abr/2012)

Os letramentos acadêmicos ocorrem como um conjunto de práticas com as quais os estudantes náo estăo familiarizados e que precisam aprender náo somente o que constitui o conhecimento relevante na disciplina, mas também o uso da linguagem. 0 sujeito diz que está há "23 anos fora da escola"e que, nas suas práticas anteriores de estudante, "nâo existia isso", referindo-se aosDiscursos científicos, na produçâo de artigos. Mas os dados mostram que isso náo ocorre só com estudantes há anos afastados da escola, pois Letícia, que, na ocasiāo, recém havia saído do Ensino Médio e logo entrou na universidade, também apresentaesses modos de interaçâo, tendo em vista que, em suas práticas escolares, ela năo possuía familiaridade com a produçăo de gêneros discursivos do domínio científico.

Da mesma forma que Vítor, Letícia demonstra alguns conflitos com o uso da linguagem, na produçấo escrita do artigo científico. Mas também demonstra que conseguiu melhorar a adequaçâo linguística e discursiva, ao longo de sua inserçâo no Pibid, construindo, assim, os letramentos acadêmicos a partir das práticas das quais participou.

(15) Nos primeiros artigos, tivemos bastante dificuldade... na escrita ou falando... a gente náo conseguia fazer mais científico, as palavras... mas, agora, os últimos já estâo mais tranquilos." (Letícia - Entrevista 1 - abril/2012) 
O enunciado indica um movimento avaliativo, em que Letícia está consciente de convençôes requeridas para uma escrita acadêmica, pois ela indica que, quanto mais especializados os gêneros acadêmicos se tornam, mais especializada fica a linguagem. Ao dizer que "nâo conseguia fazer mais científico, as palavras...", Letícia compreende que o contexto comunicativo, os interlocutores e os usos que eles fazem dos Discursos săo determinantes nas práticas de letramentos acadêmicos. Essas atividades de escrita exigem a leitura de textos especializados para construir "conceitos teóricos e metodológicos que serăo caros à sua atuaçâo profissional" (MATÊNCIO, 2006, p. 98). Convém ressaltar que a Universidade, como formadora, tem significativa parcela de participaçấo na formaçăo de um professor-pesquisador, pois a relaçấo com o saber profissional está diretamente condicionada ao saber científico.

Ainda sobre esses dados de Letícia, no início, ainda em fase de adaptaçăo da estudante às práticas do Pibid, se verificam marcas dos Discursos reciclados (GEE, 1999), isto é, a aquisiçăo parcial relativa ao metaconhecimento e às estratégias para se colocar em prática. Segundo Gee (1999), os Discursos reciclados trazem uma noçâo de tensâo ou conflito entre os Discursos de uma pessoa e nem sempre ocorrem de forma consciente ou intencional.

Para Dionísio e Fischer, existem tensōes e conflitos quanto aos gêneros e às práticas que eles sustentam (DIONÍSIO; FISCHER, 2010) em âmbito acadêmico. E isso se revela na fala da aluna, pois ela percebe que existe uma prática acadêmica, com Discursos mais especializados, que estăo se desvelando à sua frente. O relato de que teve "bastante dificuldade" indica um movimento avaliativo que mostra a tensăo que é escrever em linguagem acadêmica, pois exige conhecimentos, valores e competências que ela nâo possui, dentro de relaçôes de poder das práticas em que esses textos circulam.

Aos poucos, Letícia começou a desenvolver consciência para usar uma metalinguagem dentro de uma comunidade de prática, caracterizando os Discursos de fronteira (GEE, 2001), em que coexistem Discursos primários e secundários, isto é, Discursos do cotidiano familiar e de conhecimentos mais especializados. A estudante adquiriu a linguagem, formas de dizer, fazer e pensar pertencentes a essa comunidade, por isso sentiu que os últimos artigos foram "mais tranquilos". Esses modos de dizer săo os Discursos secundários (GEE, 2001), aprendidos na universidade, por exemplo.

Letícia, inicialmente, nâo conhecia o modo de escrita e as relaçôes de poder do contexto acadêmico-científico. Mas os conflitos fizeram com que a estudante aprendesse a conviver com esses novos letramentos, em que ela toma consciência de sua evoluçáo no processo de escrita científica:

(16) Podemos perceber que, com o passar do tempo, temos mais facilidade de escrita. Conseguimos 'encaixar' as palavras, nos expressar cientificamente e organizar as ideias no texto. (Letícia - DiárioReflexivo - ago/2012)

(17) Quanto à escrita, percebo que ainda tenho um pouco de dificuldade de transpor a linguagem do senso comum para a científica. Acredito ser muito direta com as palavras. Mas com a prática frequente deescrita a que somos estimulados, a cada dia superamos nossas barreiras. (Letícia - Entrevista 3 - ago/2013)

Há um movimento avaliativo de Letícia ao longo do processo de interaçâo no Pibid, que demonstra a familiarizaçăo com a escrita mais especializada e com os Discursos científicos. A estudante demonstra fazer uso de letramentos críticos(GEE, 1999),com 
apoio da metalinguagem, quando diz "...temos mais facilidade de escrita" (16) e "...a cada dia superamos nossas barreiras" (17). Letícia realiza escolhas nesse contexto, para a construçâo de suas próprias práticas letradas, de forma crítica, autônoma, consciente e reflexiva. Embora perceba lacunas nas construçōes necessárias para se inserir e se sentir membro dessa comunidade, como se observa em "ainda tenho um pouco de dificuldade de transpor a linguagem do senso comum para a científica" (16), Letícia começa a desenvolver uma metaconsciência para usar a linguagem dentro de uma comunidade de prática, como as formas de dizer, fazer e pensar que já săo dessa comunidade.

Letícia sente que está em processo de (trans)formaçăo e que o Pibid é o espaço que lhe possibilita uma mudança de papéis, pelas práticas sociais que fazem parte do Programa, quando diz "com a prática frequente de escrita a que somos estimulados"(17). Para Matêncio, por meio da produçáo de textos a partir de outros textos, fenômeno nomeado como retextualizaçăo, "o estudante estabelece contato tanto com o fazer-científico em sua área de formaçấo quanto com os gêneros que aí circulam e colocam em funcionamento esse domínio discursivo" (MATÊNCIO, 2006, p. 99).

Portanto, é muito significativo considerar, no caso deste curso de licenciatura em Ciências Biológicas, em benefício à formaçâo docente, modos culturais de utilizaçâo da linguagem pelos universitários. Nesses usos, estâo implícitas relaçōes de poder, reproduzidas em virtude de experiências e de conhecimentos vivenciados ao longo da vida (BARTON; HAMILTON, 2000), em "práticas socialmente situadas" (GEE, 1999), de acordo com o ambiente dentro e fora de instituiçōes formadoras e em virtude de interesses desses estudantes, de relaçóes com os outros e com a sociedade.

\section{CONSIDERAÇÕES FINAIS}

Ao analisar as (trans)formaçōes de identidades docentes, foram consideradas práticas de letramento pedagógico, como o conjunto de práticas próprias da formaçâo profissional de professores, especialmente por se tratar do Pibid como o contexto social em análise. Dessa forma, analisaram-se as interaçôes, na escrita em âmbito acadêmico e pedagógico, na produçáo do relatório e do artigo científico, gêneros com propósito de, basicamente, relatar e divulgar o trabalho pedagógico realizado. A partir das interpretaçôes de interaçôes, com apoio de movimentos dialógicos dos sujeitos, nas práticas em que esses gêneros circulam, pode-se acompanhar o como eles foram expostos a práticas que năo eram conhecidas por eles, pelo menos năo na condiçăo de professores.

Os resultados indicam uma (re)contextualizaçáo de conteúdos para a sala de aula da Educaçâo Básica, fazendo, assim, mençāo ao título deste artigo. Nessa prática, evidencia-se o início da (trans)formaçâo de alunos em professores, pois aqueles nâo estudam apenas para aprender, mas também para ensinar. Em outras palavras, esses acadêmicos precisam saber como fazer para que a aprendizagem se efetue nas práticas pedagógicas com as quais interagem no Pibid. Teoria e prática andam juntas, cumprindo as funçōes deste Programa, o qual prevê diálogo entre universidade e escola, num movimento de troca e năo apenas de transposiçấo de saberes, pois professores em formaçăo atuam junto a professores formados, uns aprendendo com os outros. 
As interaçóes centrais destacadas neste artigo referem-se às práticas de participaçăo em eventos científicos e práticas de vivência docente, que requerem Discursos próprios, de acordo com as relaçôes de poder das novas práticas de letramento. Os sujeitos foram incorporando saberes e atitudes de acordo com os novos contextos e com as novas identidades. Os depoimentos dos estudantes, sob uma perspectiva linguística e com foco na área dos letramentos, indicam que houve uma mudança de comportamento, visto que vivenciaram conflitos nas primeiras inserçôes em práticas de escrita acadêmica e pedagógica. Esses conflitos foram enfrentados em colaboraçáo com colegas e professores, com orientaçăo de professoras - a coordenadora do Projeto e a supervisora na escola - que deram apoio e acompanharam os trabalhos. Este tipo de interaçấo oportunizou, dessa forma, maior autonomia e revelaçấo de marcas de autoria aos sujeitos.

Ainda, os conflitos foram considerados momentos de aprendizagem e (trans) formaçăo, pois oportunizaram reflexâo e busca de novas possibilidades de interaçâo com os conhecimentos e com os outros. Gradativamente, esses sujeitos da pesquisa conseguiram "se sentir professores" (BARTLETT, 2007), minimizando as fronteiras entre ser aluno e ser professor. Ao se sentirem membros ativos, na interaçâo com os outros, passaram a se identificar como protagonistas de suas (trans)formaçóes de identidades docentes. Estas se caracterizam como representaçóes que se constituem na relaçăo com gêneros acadêmico-científicos e também com os que circulam em práticas pedagógicas, já que o Pibid se destina à formaçăo docente. Esses professores, ao se envolverem em práticas de letramento pedagógico, construíram novos sentidos à produçấo escrita, pois tinham muito o que dizer, a interlocutores reais, na vivência de relaçóes de poder próprias de uma esfera de atividade específica. Pouco a pouco, a compreensâo foi se ampliando acerca de elementos relativos às normas institucionais e às expectativas quanto à escrita e divulgaçăo científicas, bem como com o que e como efetivamente conseguem produzir para serem aceitos como insiders nessas práticas.

No caso das práticas de escrita, os movimentos dialógicos, em análise neste artigo, mostram-se significativos entre pibidianos, pois adotam como objeto de trabalho nos artigos as próprias práticas pedagógicas, na relaçăo com as científicas, para discutir e divulgar resultados desse complexo processo de construçăo de conhecimentos. Os dizeres dos sujeitos apontam motivaçâo e desejo que impulsionaram as aprendizagens em práticas de letramento do Pibid. Eles trouxeram os Discursos das leituras e das discussôes realizadas no grupo, recontextualizados em interaçôes das práticas pedagógicas, por meio de movimentos confirmativos e avaliativos. Com apoio de movimentos confirmativos, os dados reforçam que os estudantes incorporaram as leituras do Pibid, aproveitando o que fazia sentido para suas práticas pedagógicas, numa postura de reforçar Discursos dominantes que circulam no Pibid. Inicialmente, os sujeitos tentaram se acomodar aos Discursos do Pibid, mas, por meio das interaçôes com o conhecimento e com os outros, nas práticas de letramento, eles passaram a fazer escolhas mais conscientes. Portanto, os movimentos confirmativos năo săo de "acomodaçăo", mas de valorizaçấo aos pontos de referência ancorados nas teorias e pressupostos estudados no Pibid. Através de movimentos avaliativos, os estudantes revelaram tanto os conflitos como as formas de aprendizagem, construindo comentários críticos em relaçấo a seus letramentos e a suas (trans)formaçōes na trajetória do Pibid, com marcaçóes de uma avaliaçăo positiva na interaçăo em novas práticas de letramento. 
A discussâo realizada possibilitou uma análise de como os estudantes universitários adquirem autonomia e segurança nas práticas de letramento do domínio acadêmico e pedagógico. Mesmo que as trajetórias analisadas neste artigo tenham sido de apenas de dois sujeitos em contextos situados, espera-se trazer perspectivas viáveis para a formaçăo de professores. O ponto principal que se quer reforçar diz respeito à imersăo e às interaçôes de futuros professores em práticas pedagógicas desde o início do curso, seja por Programas Institucionais, como o Pibid, seja por iniciativa dos professores formadores, ao encaminharem suas propostas curriculares, que considerem os saberes práticos paralelamente à teoria, a fim de que se estabeleçam interaçóes significativas nos contextos de formaçăo docente.

Os letramentos sâo, portanto, (re)contextualizados nas (trans)formaçōes dos sujeitos, pois os princípios teóricos se manifestam em forma de projetos e práticas pedagógicos/as que fazem os acadêmicos se assumirem insiders na docência. No início do processo de pesquisa, vislumbraram-se identidades de alunos, com expectativas em relaçăo às práticas de letramento voltadas à docência, em que se observaram representaçóes confusas nas fronteiras entre ser aluno e ser professor. Nas interaçóes discursivas de que foram participando, em práticas de letramento do Pibid, emergiram relaçóes de poder com as quais os sujeitos foram se familiarizando, o que oportunizou mudanças conscientes em modos de pensar, sentir, falar e agir, fazendo com que identidades docentes fossem(re)construídas. 


\section{REFERÊNCIAS}

BAKHTIN, M. Estética da criaçăo verbal. Traduçăo de Paulo Bezerra. 6. ed. Săo Paulo: Martins Fontes, 2011.

- Marxismo e filosofia da linguagem. Traduçăo de Michel Lahud; Yara Teixeira Wisnik. 10. ed. Sáo Paulo: Annablume, 2002.

BARTLETT, L. To seem and to feel: situated identies and literacy practices. Teachers College Record. Columbia University, v. 109, n. 1, pp. 51-69, January 2007.

BARTON, D.; HAMILTON, M. Literacy pratices. In: BARTON, D. et. al. Situated literacies: reading and writing in context. London: Routledge, 2000. pp. 7-15.

BAUER, M. W.; GASKELL, G. Pesquisa qualitativa com texto, imagem e som: um manual prático. Traduçăo de Pedrinho A. Guareschi. Petrópolis: Vozes, 2002.

BAUMAN, Z. Identidade: entrevista a Benedetto Vecchi. Traduçăo de Carlos Alberto Medeiros, Rio de Janeiro: Zahar, 2005.

BOGDAN, R. C; BIKLEN, S. K. Investigaçăo qualitativa em educaçăo: uma introduçâo à teoria e aos métodos. Traduçâo de Maria Joăo Alvarez, Sara Bahia dos Santos e Telmo Mourinho Baptista. Porto: Porto Editora, 1994.

BOHN, H. I. A formaçâo do professor de línguas: a construçâo de uma identidade profissional. Investigaçóes: linguística aplicada e teoria literária. Recife: UPE, v. 17, n. 2, 2005, pp. 97-113.

COLAÇO, S. F. A travessia do ser aluno para o ser professor: práticas de letramento pedagógico no Pibid. 2015. 214 f. Tese (Doutorado em Linguística Aplicada) - Pós-Graduaçāo em Letras, Universidade Católica de Pelotas, Pelotas, 2015.

DENZIN, N. K.; LINCOLN, Y. S. 0 planejamento da pesquisa qualitativa: teorias e abordagens. Traduçăo de Sandra Regina Netz. 2. ed. Porto Alegre: ARTMED, 2006.

DIONÍSIO, M. L.; FISCHER, A. Literacia(s) no ensino superior: configuraçōes em práticas de investigaçâo. In: VIEIRA, F. (Org.). Actas do Congresso Ibérico Ensino Superior em Mudança: Tensóes e Possibilidades. Braga: CIED, Universidade do Minho, 2010. 1CD-ROM.

FIAD, R. S. A escrita na universidade. ABRALIN, v. Eletrônico, n. Especial, pp. 357-369, $2^{\mathrm{a}}$ parte, 2011.

FIAD, R. S.; SILVA, L. L. M. da. Escrita na formaçâo docente: relatos de estágio. Acta do Scientiarum. Language and Culture. Maringá, v. 31, n. 2, pp. 123-131, 2009.

FISCHER, A. "Hidden Features" and "Overt Instruction" in academic literacy practices: a casestudy in engineering. In: LILLIS, T.; HARRINGTON K.; LEA, M.; MITCHELLL, S. (Ed.). Working with academic literacies: research, theory, design. Colorado: The WAC Clearinghouse; Parlor Press, pp. 75-85, 2015. Disponível em <http://wac.colostate.edu/ books/lillis/>. Acesso em: 15 nov. 2015.

Literacias em contexto acadêmico: construçōes e sentidos. Língua Portuguesa: ultrapassar fronteiras, juntar culturas. Universidade de Évora, 2010. Disponível em: <http://www.simelp2009.uevora.pt/pdf/slg14/17.pdf>. Acesso em: 10 jul. 2012. 
Letramento acadêmico: uma perspectiva portuguesa. Acta Scientiarum. Language and Culture, v. 30, n. 2, pp. 177-187, 2007.

GEE, J. P. Reading as situated language: a sociocognitive perspective. Journal of adolescent $\mathcal{Q}$ adult literacy, v. 8, n. 44, pp. 714-725, 2001.

. Social linguistics and literacies: ideology in discourses. 2. ed. London/Philadelphia: The Farmer Press, 1999.

HALL, S. Quem precisa da identidade? In: SILVA, T. T. (Org.). Identidade e diferença: a perspectiva dos estudos culturais. 11. ed. Petrópolis, RJ: Vozes, 2012. pp. 103-133

A identidade cultural na pós-modernidade. Traduçăo de Tomaz Tadeu da Silva e Guacira Lopes Louro. 11. ed., Rio de Janeiro: DP\&A, 2011.

KLEIMAN, A. B. Processos identitários na formaçâo profissional: o professor como agente de letramento. In: CORREAA, M. L. G; BOCH, F. (Org.). Ensino de Língua: representaçăo e letramento. Campinas, SP: Mercado de Letras, 2006. pp. 75-91

LEA. M. R.; STREET, B. V.The academic literacies model: theory and applications. Theory into Practice, v. 45, n. 4, pp. 368-377, 2006.

Student writing in higher education: an academic literacies approach. Studies in Higher Education. London, v. 23, n. 2, p. 157-16, June, 1998.

LILLIS, T. M. Bringing writers' voices to writing research: talk around texts. In: CARTER, A.; LILLIS, T.; PARKIN, S. (Ed.) Why writing matters: issues of access and identity in writing research and pedagogy. Amsterdam: John Benjamins,2009, p. 169-187.

Student writing as 'academic literacies': drawing on Bakhtin to move from critique to design. Language and Education. v. 3, n. 17, pp. 192-207, 2003.

_. Student writing: access, regulation, desire. Literacies. UK: Routledge, 2001.

. Whose 'common sense'? Essayist literacy and the institutional practice of mystery. In: JONES, C.; TURNER, J.; STREET, B. (Org.). Students writing in the university: cultural and epistemological issues. Amsterdam: John Benjamins, 1999, pp. 127-140.

LILLIS, T.; SCOTT, M. Defining academic literacies research: issues of epistemology, ideology and strategy. Journal of Applied Linguistics, v. 4, n. 1, pp. 5-32, 2007.

MATÊNCIO, M. L. M. Letramento na formaçăo do professor - integraçâo a práticas discursivas acadêmicas e construçăo da identidade profissional. In: CORRÊA, M. L. G. (Org.). Ensino de língua: representaçăo e letramento.Campinas/SP: Mercado de Letras, 2006, pp. 93-105.

NÓVOA, A. Formaçăo de professores e profissăo docente. In: (Coord.). Os professores e a sua formaçấo. Lisboa: Dom Quixote, 1992. pp. 13-33 Disponível em: <http://hdl.handle.net/10451/4758>.Acesso em: 12 nov. 2014.

POLLAK, M. Memória e identidade social. Estudos Históricos, Rio de Janeiro, v. 5, n. 10, p. 200-212, 1992.

SILVA, T. T. A produçăo social da identidade e da diferença. In: (Org.). Identidade e diferença: a perspectiva dos estudos culturais. 11.ed. Petrópolis, RJ: Vozes, 2012.

SOBRAL, A. Do dialogismo ao gênero: as bases do pensamento do Círculo de Bakhtin. Campinas, SP: Mercado de Letras, 2009. 
STREET B. Letramentos sociais: abordagens críticas do letramento no desenvolvimento, na etnografia e na educaçăo. Traduçâo de Marcos Bagno. Săo Paulo: Parábola, 2014.

Dimensóes "escondidas" na escrita de artigos acadêmicos. Traduçấo de Armando Silveiro e Adriana Fischer. Perspectiva: Revista do Centro de Ciências da Educaçấo UFSC, Florianópolis, v. 8, n. 2, pp. 541-567, jul./dez., 2010.

. Entrevista com Brian Street. Entrevista concedida a Gilcinei Teodoro Carvalho e Marildes Marinho. Traduçâo de Gilcinei Teodoro Carvalho. Língua Escrita. n. 7, jul./dez. 2009. Disponível em: 〈http://www.ceale.fae.ufmg.br〉. Acesso em: 24 jan. 2012.

Perspectivas interculturais sobre o letramento. Filologia linguística do português,

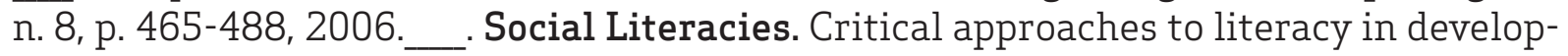
ment, ethnography and education. Halrow: Pearson, 1995.

THE NEW LONDON GROUP.A pedagogy of multiliteracies: designing social futures. Harvard Educational Review, v. 66, n. 1, pp. 60-92, 1996. Disponível em: <http://newarcproject.pbworks.com>. Acesso em: 15 set.2016.

WOODWARD, K. Identidade e diferença: uma introduçăo teórica e conceitual. In: SILVA, T. T. (Org.) Identidade e diferença: a perspectiva dos estudos culturais. 11 ed. Petrópolis, RJ: Vozes, 2012. 